\title{
Translation, cross-cultural adaptation and psychometric evaluation of yoruba version of the short-form 36 health survey
}

Chidozie Emmanuel Mbada ${ }^{1,2^{*}}$, Gafar Atanda Adeogun ${ }^{1}$, Michael Opeoluwa Ogunlana ${ }^{3}$, Rufus Adesoji Adedoyin ${ }^{1}$, Adesanmi Akinsulore ${ }^{4}$, Taofeek Oluwole Awotidebe ${ }^{1}$, Opeyemi Ayodiipo Idow ${ }^{5}$ and Olumide Ayoola Olaoye ${ }^{1}$

\begin{abstract}
Background and objective: The Short-Form Health Survey (SF-36) is a valid quality of life tool often employed to determine the impact of medical intervention and the outcome of health care services. However, the SF-36 is culturally sensitive which necessitates its adaptation and translation into different languages. This study was conducted to cross-culturally adapt the SF-36 into Yoruba language and determine its reliability and validity.

Methods: Based on the International Quality of Life Assessment project guidelines, a sequence of translation, test of item-scale correlation, and validation was implemented for the translation of the Yoruba version of the SF-36. Following pilot testing, the English and the Yoruba versions of the SF-36 were administered to a random sample of 1087 apparently healthy individuals to test validity and 249 respondents completed the Yoruba SF-36 again after two weeks to test reliability. Data was analyzed using Pearson's product moment correlation analysis, independent $t$-test, one-way analysis of variance, multi trait scaling analysis and Intra-Class Correlation (ICC) at $p<0.05$.

Results: The concurrent validity scores for scales and domains ranges between 0.749 and 0.902 with the highest and lowest scores in the General Health (0.902) and Bodily Pain (0.749) scale. Scale-level descriptive result showed that all scale and domain scores had negative skewness ranging from -2.08 to -0.98 . The mean scores for each scales ranges between 83.2 and 88.8. The domain scores for Physical Health Component and Mental Health Component were $85.6 \pm 13.7$ and $85.9 \pm 15.4$ respectively. The convergent validity was satisfactory, ranging from 0.421 to 0.907 . Discriminant validity was also satisfactory except for item ' 1 '. The ICC for the test-retest reliability of the Yoruba SF-36 ranges between 0.636 and 0.843 for scales; and 0.783 and 0.851 for domains.
\end{abstract}

Conclusion: The data quality, concurrent and discriminant validity, reliability and internal consistency of the Yoruba version of the SF-36 are adequate and it is recommended for measuring health-related quality of life among Yoruba population.

Keywords: Health-related quality of life, Yoruba SF-36, Translation, Cultural adaptation, Psychometric properties

\section{Introduction}

Health-Related Quality of Life (HRQoL) is distinguished from quality of life in that it is concerned primarily with those factors that fall under the purview of health care providers and health care system [1]. HRQoL as a multidimensional concept describes the effect of diseases and

\footnotetext{
* Correspondence: doziembada@yahoo.com

${ }^{1}$ Department of Medical Rehabilitation, College of Health Sciences, Obafemi Awolowo University, Ile - Ife, Nigeria

${ }^{2}$ African Population and Health Research Center, Nairobi, Kenya

Full list of author information is available at the end of the article
}

illnesses on persons' physical, social and mental wellbeing $[2,3]$ and it is important in estimating the efficacy of medical intervention on quality of life [4-6] and also to monitor community health $[2,3]$.

Literature is replete on various HRQoL measures or test batteries which can either be generic or disease-specific $[2-5,7-11]$. Amid the various measurement tools, the Medical Outcomes Study (MOS) Short Form 36-item Health Survey (SF-36), is one of the most widely used generic measures of HRQoL with good psychometric properties and substantial data on its applicability in clinical and 
research settings [6, 9-14]. The SF-36 was derived from the original 245 items RAND MOS Questionnaire as a set of generic, coherent, and easily administered quality of life measures $[9,10,15]$. The 36 items health survey tool assesses eight health dimensions referred to as subscales, namely Physical Functioning (PF: 10 items), Role Limitations due to Physical Problems (RP: 4 items), Bodily Pain (BP: 2 items), General Health (GH: 5 items), Vitality (VT: 4 items), Social Functioning (SF: 2 items), Role Limitation due to Emotional Problems (RE: 3 items) and Mental Health (MH: 5 items) $[9,10]$. These subscales' scores are summarized into physical and mental composite domains $[9,10]$. Individual SF-36 items are recoded, summed and transformed. The health concepts described by the SF-36 range in score from $0-100$, with higher scores indicating higher levels of function or better health. Scores on the eight subscales can be used to compute a summary index of Physical Health Component (PC) and Mental Health Component $(\mathrm{MC})$ respectively $[9,10]$.

The SF-36 has been employed to compare quality of life between different disease groups and populations [7, 16]. However, Cheung [17] opined that the SF-36 scores cannot be used to make valid inferences about racial/ethnic group differences when measurement equivalence is not provided, such differences might be due to item response bias rather than true differences in selfreported health. Non-equivalence can occur when differences in values, attitudes, language and overall world view cause respondents to respond to survey questions differently, leading to differential item functioning [18]. Therefore, the cultural sensitivity and bias of the SF-36 necessitates its adaptation and translation into different languages. Consequently, the SF- 6 has been translated for use in both general and condition-specific populations in many languages such as Arabic [14], Chinese [19], Malay [20] and Persian [21] among others.

The SF-36 has been used by some Nigerian researchers [22-26], with two studies reporting content and criterion validity of its Yoruba translations among patients with hypertension [25] and low-back pain [26] respectively. However, cross-cultural adapted versions of the SF-36 in indigenous Nigerian languages based on internationally accepted guidelines seems not to be available for referencing. Therefore, this study was conducted to cross-culturally adapt the SF-36 into Yoruba language and determine its reliability and validity. Yoruba is one of the major Nigerian languages spoken in Southwest Nigeria, and also in countries like Benin and Togo. In addition, there is a pocket of Yoruba population especially in the UK, Brazil and the USA [27, 28].

\section{Methods}

The study protocol was approved by the Ethical Review Committee, Institute of Public Health, College of Health
Sciences, Obafemi Awolowo University, Ile-Ife, Nigeria (IPHOAU/12/156). A total of 1087 (657 males and 430 females) individuals comprising of students, workers and other residents of Ile-Ife, Osun state, Nigeria volunteered for this study, yielding a response rate of $98.8 \%$ (i.e. 1087/ 1100). Informed consent was obtained from all the respondents. Eligible respondents were 18 years and older, literate in English and Yoruba languages and with no reported history of cognitive or mental impairment or current medical condition. A multistage sampling technique was employed in the study. Respondents from Obafemi Awolowo University, Ile-Ife comprised of students and staff. The students were recruited from four randomly selected students' halls of residence (two for male and female students respectively). Every odd numbered room in each block in the halls of residence was sampled. Staff respondents were volunteers sampled from ten randomly selected departments using a fishbowl technique. Respondents who were resident outside the university community were recruited based on the World Health Organization guideline for conducting community surveys [29]. These respondents were randomly selected from five out of eleven political wards of Ile-Ife Local Government Area. Every odd numbered house was selected for survey.

Based on the International Quality of Life Assessment (IQOLA) Project, the English version of the SF-36 was translated into Yoruba language. The IQOLA project was established in 1991 with the goal of developing validated translations of a health status questionnaire as required for their use internationally in order to avoid bias in interpretation and adaptation $[10,19,30]$.

The protocol was carried out in sequential order as highlighted by Fukuhara et al. [12]:

a. Forward translation of the items and response choices of the English version of the SF-36 into Yoruba language by two native Yoruba speakers with fluency in English (Translator A and B). These translators are linguists and educators in Yoruba language at the University who worked independently to produce two initial Yoruba versions of the SF-36. Both translators were instructed, as described in the IQOLA protocol, to aim for conceptual rather than literal translation and to keep the language colloquial and compatible with a reading level of age 14 as described by Fukuhara et al. [12]. The translators were also asked to give difference translations for each response choice where possible.

b. Harmonization and reconciliation of the two different translations was carried out. Another 
bilingual translator reviewed the items in the two Yoruba translated questionnaires in order to produce a single, reconciled and harmonized translation. Based on consensus among the translators, items were included in the reconciled translation. For items that were linguistically or culturally problematic, the translators decided on the most acceptable option after exhausting all reasonable options.

c. Two natives who were literate in oral and written Yoruba language assessed the Yoruba consensus translation for comprehensibility and ambiguity on the difficulty and quality rating in terms of clarity, common language usage, and conceptual equivalence. A scale of 0 to 100 (0 means "not at all difficult" and 100 means "extremely difficult") was used for difficulty rating, while quality rating was also rated on a scale of 0 to 100 (where 100 indicate perfection). First assessor rated the harmonized translation 70 and $80 \%$ on difficulty and quality scale respectively, while the other assessor rating was 80 and $90 \%$ for difficulty and quality scale respectively.

d. The harmonized forward translation was back translated into English by two bilingual (English and Yoruba) professional translator for conceptual equivalence with the original source version.

e. In order to validate the back translated English version by comparing it with the source English version, independent rating of the equivalence of the backward translations to the English version was carried out.

f. Problematic items and response options were reconciled through an iterative procedure.

g. The pre-final version of the Yoruba SF-36 was pilot tested among 32 individuals. The pilot test was aimed to explore the clarity and applicability of the translated Yoruba SF-36 in terms of perception, understanding of various terminologies used and interpretations. The results of the cognitive debriefing from the pilot study was used to further refine the pre-final version in terms of words used and the format or layout of the questionnaire.

The clustering and ordering of items in the translated Yoruba SF-36 was the same as the English version of the SF-36. However, in order to give the translated Yoruba SF-36 a conceptual equivalence to the English SF-36, arrangement and wording of some parts of the questionnaire were altered. The following cultural adaptations were made to the translated Yoruba SF-36:

i. Alphabetic numbering of the translated Yoruba SF-36 is not consistent with the English version. The alteration in the alphabetic numbering was because ' $C$ ' does not exist in the Yoruba alphabets, meanwhile alphabets such 'E' and 'GB' which are in the Yoruba does not exist in the English alphabets. For example, the first eight Yoruba alphabets are $-\mathrm{a}$, b, d, e, e , f, g, gb. Therefore, 'd' is the 3rd and 'gb' is the 8th Yoruba alphabet, hence the alphabetic numbering alteration of the translated Yoruba SF-36.

ii. Item 1 was rearranged in order to enhance its meaning in Yoruba language (This is because instruction comes before question).

iii. In question ' $3 b$ ', "pushing a vacuum cleaner and bowling" were changed into "floor mopping and archery" respectively. Pushing a vacuum cleaner and bowling are uncommon activities in the study context. Therefore "floor mopping" was considered as an alternative moderate activity for "pushing vacuum cleaner". On the other hand, bowling which refers to a number of sports or activities involving throwing a bowling ball towards a target, is strange to the Yoruba culture. However, archery which also refers to a sport involving shooting arrows at a target using a bow can easily be related with by the Yoruba people.

iv. 'Blocks' as a measure of distance in questions ' $3 \mathrm{~h}$ ' and '3i' of the English SF-36 (which corresponds to '3gb' and ' $3 i$ ' in the Yoruba SF-36) were changed in the Yoruba SF-36 to 'electric pole distance'. This is because blocks are less known as a descriptive measure of distance in the study setting compared with electric pole distance. However, the distance between two high tensions electric poles are commonly $50 \mathrm{~m}$, which is not an equivalent of 'one block" that actually means a distance of $100 \mathrm{~m}$. Nonetheless, it also known that distance between blocks are not fixed and varies widely in different setting.

Respondents completed both English and Yoruba versions of SF-36 as well as questions on socio-demographic variables. Thereafter, the respondents rated the English and Yoruba versions of SF-36 separately based on standard method of rating SF-36 Questionnaire recommended by IQOLA on the same day. Two weeks later, the respondents were asked to rate their quality of life on the Yoruba version of SF-36 again and the scores were compared with the initial rating.

Computation of the SF-36 involves, firstly, recoding of the pre-coded numeric values based on SF-36 scoring key for the required 35 out of the 36 items. Each item is recoded on a 0 to 100 range. Items " $1,2,6,8,11 b, 11 d$ " with pre-coded numeric values 1 through 5 , are recoded inversely to values of $100,75,50,25$, and 0 respectively. Items "7, 9a, 9d, 9e, $9 \mathrm{~h}$ " with pre-coded 1 through 6, are recoded inversely to values of 100, 80, 60, 40, 20 and 0 respectively. On the other hand, items " $3 \mathrm{a}, 3 \mathrm{~b}, 3 \mathrm{c}, 3 \mathrm{~d}$, 
3e, $3 \mathrm{f}, 3 \mathrm{~g}, 3 \mathrm{~h}$, 3i" with pre-coded numeric values, 1 through 3 are recoded in the same direction to values of 0,50 and 100 respectively. Items in " $4 \mathrm{a}, 4 \mathrm{~b}, 4 \mathrm{c}, 4 \mathrm{~d}, 5 \mathrm{a}$, $5 \mathrm{~b}, 5 \mathrm{c}$ " with pre-coded numeric values, 1 and 2 are recoded in the same direction to values of 0 and 100 respectively. Items in "10, 11a, 11c" with pre-coded numeric values, 1 through 5 are recoded in the same direction to values of $0,25,50,75$ and 100 respectively, while items in "9b, 9c, 9f, 9 g, 9i" with precoded numeric values, 1 through 6 are recoded in the same direction to values of $0,20,40,60,80$ and 100 respectively.

Secondly, items in the same hypothesized scale are computed and averaged together to create the eight scale scores. The scales and the constituent items are 1) GH -"1, 11a, 11b, 11c, 11d"; 2) PF - "3a, 3b, 3c, 3d, 3e, 3f, 3 g, 3 h, 3i, 3j"; 3) RP - "4a, 4b, 4c, 4d"; 4) RE - "5a, 5b, 5c"; 5) SF - "6, 10"; 6) $\mathrm{MH}$ - “9b, 9c, 9d, 9f, 9 h"; 7) BP - “7, 8"; and 8) VT - "9a, 9e, 9 g, 9i". Thirdly, scales in the same domain are computed and averaged together to create the two domain scores. The domains and the constituent scales are 1) PC - "GH, PF, RP, BP"; and 2) MC - "MH, RE, SF, VT".

In order to determine the psychometric properties of the Yoruba version of the SF-36, it was hypothesized that items, scales and domain scores would correlate significantly $(\mathrm{r}>0.40)$ with the English SF36. Based on correlation co-efficient $(r)$ cut-off points for high $(=>0.70)$, moderate $(0.4-<0.7)$ and low $(<0.40)$, high correlations $(>0.70)$ were considered desirable because this would indicate good validity of the translated Yoruba SF-36 (Appendix).

\section{Data analysis}

Descriptive statistics of scales and domains of the Yoruba version of SF-36 was determined by analyzing mean score, confidence interval, skewness and Kurtosis. Concurrent validity of the Yoruba SF-36 was determined by correlating scores of English and Yoruba versions of the SF-36 using Pearson's product moment correlation. Intra class correlation (ICC) was used to determine the reliability (test-retest) of the Yoruba SF-36. Multi trait scaling analysis (i.e. item-scale correlations) was used to confirm item discriminant validity (i.e. correlations between each item and its hypothesized scale). Knowngroups validity of Yoruba version of SF-36 was tested by comparing scale and domain scores by gender and age groups using independent $t$-test and One-way ANOVA respectively. Data was analyzed using SPSS (Statistical Package for Social Sciences) version 16.0. Alpha level was set at $p<0.05$.

\section{Results}

The respondents' ages ranges between 18 and 70 years with the mean of $27.9 \pm \mathrm{SD} 9.48$ years. The socio- demographic characteristics of the respondents are presented in Table 1 . The respondents were mostly of the Yoruba tribe (95.8\%), single (67.8 \%), Christians $(41.3 \%)$ and had tertiary education $(83.8 \%)$. The mean, confidence interval, skewness and Kurtosis of mean scores for the eight scales/dimensions of the Yoruba version of SF-36 are presented in Table 2. The result shows that the mean scores for the scales range between 83.2 and 88.8. The highest and lowest scores were observed in the $\mathrm{MH}$ (88.8) and RE (83.2). PC and $\mathrm{MC}$ domain scores was $85.6 \pm 13.7$ and $85.9 \pm 15.4$ respectively. The scale and domain scores yielded negative skewness ranging from $-2.08--0.98$ on the Yoruba version of SF-36.

Table 3 shows the Pearson correlation analysis between respondents' scores on the English and Yoruba

Table 1 Socio-demographic characteristic of the respondents $(n=1087)$

\begin{tabular}{|c|c|c|}
\hline Variables & Frequency & $\%$ \\
\hline \multicolumn{3}{|l|}{ Age group } \\
\hline $18-24$ & 475 & 43.80 \\
\hline $25-34$ & 447 & 41.12 \\
\hline $35-44$ & 79 & 7.27 \\
\hline $45-54$ & 51 & 4.69 \\
\hline$\geq 55$ & 35 & 3.22 \\
\hline \multicolumn{3}{|l|}{ Gender } \\
\hline Male & 657 & 60.4 \\
\hline Female & 430 & 39.6 \\
\hline \multicolumn{3}{|l|}{ Marital status } \\
\hline Single & 737 & 67.8 \\
\hline Married & 335 & 30.8 \\
\hline Widowed & 10 & 0.9 \\
\hline Divorced & 5 & 0.5 \\
\hline \multicolumn{3}{|l|}{ Ethnic group } \\
\hline Hausa & 9 & 0.8 \\
\hline Igbo & 14 & 1.3 \\
\hline Yoruba & 1041 & 95.8 \\
\hline Others & 23 & 2.1 \\
\hline \multicolumn{3}{|l|}{ Religion } \\
\hline Christianity & 626 & 57.6 \\
\hline Islam & 449 & 41.3 \\
\hline Traditional & 12 & 1.1 \\
\hline \multicolumn{3}{|l|}{ Education level } \\
\hline No formal & 2 & 0.2 \\
\hline Primary & 8 & 0.7 \\
\hline Secondary & 166 & 15.3 \\
\hline Tertiary & 911 & 83.8 \\
\hline
\end{tabular}


Table 2 The mean score, standard deviation, confidence interval, Skewness and kurtosis of each scales and components (domains) of Yoruba SF-36 $(n=1087)$

\begin{tabular}{|c|c|c|c|c|c|c|c|c|c|c|}
\hline & \multicolumn{7}{|l|}{ Scale } & \multicolumn{3}{|c|}{$\underline{\text { Domain }}$} \\
\hline & $\overline{\mathrm{GH}}$ & $\mathrm{PF}$ & $\mathrm{RP}$ & RE & SF & $\mathrm{MH}$ & $\mathrm{BP}$ & $\overline{\mathrm{VT}}$ & PC & $M C$ \\
\hline Mean & 86.9 & 86.1 & 85.1 & 83.2 & 84.6 & 88.8 & 84.8 & 86.8 & 85.6 & 85.9 \\
\hline SD & 16.9 & 18.2 & 24.2 & 29.0 & 18.1 & 13.4 & 17.7 & 15.4 & 13.7 & 15.4 \\
\hline \multicolumn{11}{|c|}{ Confidence interval } \\
\hline Lower & 84.7 & 84.8 & 83.7 & 81.5 & 83.5 & 88.0 & 83.7 & 85.8 & 83.9 & 85.0 \\
\hline Upper & 89.1 & 87.4 & 86.5 & 85.0 & 85.7 & 89.6 & 85.987 .7 & 87.4 & 86.8 & \\
\hline Skewness & -2.08 & -1.64 & -1.56 & -1.71 & -1.06 & -1.17 & -1.27 & -1.25 & -0.98 & -1.15 \\
\hline Kurtosis & 4.76 & 2.17 & 1.68 & 1.90 & 0.42 & 1.23 & 1.24 & 0.98 & 0.19 & 0.87 \\
\hline
\end{tabular}

Key: Scales: physical functioning $(P F)$, role limitations due to physical problems $(R P)$, bodily pain $(B P)$, general health $(G H)$, vitality $(V T)$, social functioning $(S F)$, role limitations due to emotional problems $(R E)$, and mental health $(\mathrm{MH})$. Domains: physical health component $(P C)$ and mental health components $(M C)$

SF-36 (concurrent validity). The correlation coefficient ( $r$ ) of the scales and domains ranges between 0.749 and 0.902. GH and BP had the highest $(r=0.902)$ and lowest $(r=0.749)$ correlation coefficient respectively. Correlations between each item and its hypothesized scale (i.e. scale score computed from all other items in that scale as a test of item internal consistency) were all above 0.50 , except for item 1 and $\mathrm{GH}$ (i.e. "In general, would you say your health is') where $r=0.421$. The highest item-scale correlation coefficient was between item 8 and other items on the BP sub-scale

Table 3 Pearson correlation analysis between respondents' scores on the English and Yoruba SF-36 (concurrent validity) $(n=1087)$

\begin{tabular}{|c|c|c|}
\hline & $r$ & $p$-value \\
\hline \multicolumn{3}{|l|}{ Scale } \\
\hline $\mathrm{GH}$ & 0.902 & $0.001^{*}$ \\
\hline PF & 0.845 & $0.001^{*}$ \\
\hline $\mathrm{RP}$ & 0.813 & $0.001^{*}$ \\
\hline RE & 0.838 & $0.001^{*}$ \\
\hline SF & 0.845 & $0.001^{*}$ \\
\hline $\mathrm{MH}$ & 0.811 & $0.001^{*}$ \\
\hline $\mathrm{BP}$ & 0.750 & $0.001^{*}$ \\
\hline VT & 0.801 & $0.001^{*}$ \\
\hline \multicolumn{3}{|c|}{ Domain } \\
\hline PC & 0.839 & $0.001^{*}$ \\
\hline$M C$ & 0.887 & $0.001^{*}$ \\
\hline
\end{tabular}

Alpha level was set at $p<0.05$; ${ }^{*}$ indicate significance at $p=0.001 ; r=$ Pearson's correlation coefficient

Key: Scales; physical functioning $(P F)$, role limitations due to physical problems $(R P)$, bodily pain $(B P)$, general health $(G H)$, vitality $(\mathrm{VT})$, social functioning $(S F)$, role limitations due to emotional problems $(R E)$, and mental health $(M H)$.

Domains; physical health component $(P C)$ and mental health components $(M C)$ yielding a correlation co-efficient of 0.907 (i.e. "During the past four weeks, how much did pain interfere with your normal work -including both work outside the home and housework"). The details for item-scale correlations (discriminant validity) for Yoruba SF-36 is presented in Table 4. The result shows that items in VT, SF and $\mathrm{MH}$ scales had correlation scores greater than 0.23 with scales other than their hypothesized scales except the correlations between item 9a ("Did you feel full of pep?") and each of RP (0.192) and PF (0.146). Correlations of item $11 \mathrm{c}$ ("I expect my health to get worse") of $\mathrm{GH}$ with other scales were less than 0.3 . Correlations of items in hypothesized GH scale with items in $\mathrm{MH}, \mathrm{BP}$ and EF scales were less than 0.3 except correlations between 4b ("Accomplished less than you would like") and GH; and 4c ("Were limited in the kind of work or other activities") with each of $\mathrm{MH}$ and EF (Table 4).

For the known-groups validity of the Yoruba version of the SF-36 by gender and age, Table 5 shows the result of the independent $t$-test comparison of scales and domains by gender. The result showed that men had significant higher mean scores in $\mathrm{GH}$ $(p=0.022), \operatorname{RP}(p=0.054), \operatorname{RE}(p=0.013)$ and SF $(p=$ $0.013)$ scales respectively. There were no significant gender differences in domain scores $(p>0.05)$. On the other hand, Table 6 shows the result of the One-way ANOVA comparison of scales and domains by age group. There were significant differences in the mean scores of the Yoruba SF-36 scales and domains $(p<0.05)$. The younger age group $(18-24$ years $)$ had significantly higher mean scale and domain mean scores $(p<0.05)$. A decline in mean scores with higher age was observed across the different scales and domains except within the age bracket 35-44 years where high mean scores were found (except for $\mathrm{GH}$ scale). 
Table 4 Item-scale correlations (discriminant validity) of the Yoruba SF-36 ( $n=1087$ )

\begin{tabular}{|c|c|c|c|c|c|c|c|c|c|}
\hline & & $\mathrm{GH}$ & PF & $\mathrm{RP}$ & RE & SF & $\mathrm{MH}$ & $\mathrm{BP}$ & VT \\
\hline$\overline{\mathrm{GH}}$ & 1 & 0.421 & 0.372 & 0.324 & 0.431 & 0.460 & 0.418 & 0.428 & 0.437 \\
\hline $\mathrm{GH}$ & $11 a$ & 0.749 & 0.411 & 0.283 & 0.329 & 0.364 & 0.331 & 0.347 & 0.327 \\
\hline $\mathrm{GH}$ & $11 b$ & 0.789 & 0.339 & 0.283 & 0.284 & 0.420 & 0.365 & 0.280 & 0.376 \\
\hline $\mathrm{GH}$ & $11 c$ & 0.565 & 0.265 & 0.128 & 0.013 & 0.155 & 0.143 & 0.216 & 0.139 \\
\hline $\mathrm{GH}$ & $11 d$ & 0.780 & 0.297 & 0.225 & 0.214 & 0.303 & 0.314 & 0.294 & 0.491 \\
\hline PF & $3 a$ & 0.237 & 0.635 & 0.411 & 0.358 & 0.456 & 0.326 & 0.317 & 0.334 \\
\hline $\mathrm{PF}$ & $3 b$ & 0.242 & 0.625 & 0.373 & 0.255 & 0.391 & 0.388 & 0.342 & 0.342 \\
\hline PF & $3 c$ & 0.264 & 0.665 & 0.395 & 0.255 & 0.376 & 0.359 & 0.338 & 0.343 \\
\hline PF & $3 d$ & 0.158 & 0.742 & 0.317 & 0.320 & 0.240 & 0.303 & 0.264 & 0.279 \\
\hline $\mathrm{PF}$ & $3 e$ & 0.195 & 0.577 & 0.272 & 0.275 & 0.353 & 0.325 & 0.305 & 0.324 \\
\hline PF & $3 f$ & 0.122 & 0.590 & 0.207 & 0.206 & 0.320 & 0.218 & 0.285 & 0.230 \\
\hline $\mathrm{PF}$ & $3 \mathrm{~g}$ & 0.477 & 0.728 & 0.465 & 0.307 & 0.383 & 0.327 & 0.353 & 0.274 \\
\hline PF & $3 \mathrm{~h}$ & 0.250 & 0.748 & 0.405 & 0.366 & 0.319 & 0.266 & 0.283 & 0.280 \\
\hline PF & $3 i$ & 0.139 & 0.559 & 0.291 & 0.299 & 0.353 & 0.264 & 0.266 & 0.248 \\
\hline PF & $3 j$ & 0.159 & 0.571 & 0.283 & 0.284 & 0.293 & 0.322 & 0.332 & 0.285 \\
\hline $\mathrm{RP}$ & $4 a$ & 0.219 & 0.347 & 0.536 & 0.269 & 0.158 & 0.169 & 0.141 & 0.205 \\
\hline $\mathrm{RP}$ & $4 b$ & 0.323 & 0.440 & 0.754 & 0.401 & 0.384 & 0.293 & 0.282 & 0.275 \\
\hline $\mathrm{RP}$ & $4 c$ & 0.193 & 0.430 & 0.659 & 0.390 & 0.369 & 0.372 & 0.282 & 0.321 \\
\hline $\mathrm{RP}$ & $4 d$ & 0.056 & 0.287 & 0.641 & 0.409 & 0.309 & 0.195 & 0.208 & 0.217 \\
\hline $\mathrm{RE}$ & $5 a$ & 0.252 & 0.287 & 0.337 & 0.692 & 0.344 & 0.340 & 0.274 & 0.342 \\
\hline RE & $5 b$ & 0.246 & 0.262 & 0.387 & 0.720 & 0.387 & 0.315 & 0.296 & 0.341 \\
\hline RE & $5 c$ & 0.291 & 0.274 & 0.385 & 0.780 & 0.391 & 0.399 & 0.258 & 0.379 \\
\hline SF & 6 & 0.395 & 0.399 & 0.393 & 0.552 & 0.854 & 0.544 & 0.538 & 0.561 \\
\hline SF & 10 & 0.360 & 0.383 & 0.421 & 0.427 & 0.870 & 0.586 & 0.541 & 0.563 \\
\hline $\mathrm{MH}$ & $9 b$ & 0.433 & 0.400 & 0.400 & 0.428 & 0.478 & 0.785 & 0.423 & 0.645 \\
\hline $\mathrm{MH}$ & $9 c$ & 0.418 & 0.512 & 0.395 & 0.409 & 0.516 & 0.741 & 0.552 & 0.576 \\
\hline $\mathrm{MH}$ & $9 d$ & 0.487 & 0.255 & 0.228 & 0.260 & 0.488 & 0.738 & 0.499 & 0.623 \\
\hline $\mathrm{MH}$ & gf & 0.396 & 0.239 & 0.277 & 0.388 & 0.513 & 0.770 & 0.453 & 0.641 \\
\hline $\mathrm{MH}$ & $9 \mathrm{~h}$ & 0.479 & 0.271 & 0.276 & 0.299 & 0.474 & 0.667 & 0.440 & 0.601 \\
\hline $\mathrm{BP}$ & 7 & 0.437 & 0.433 & 0.357 & 0.468 & 0.603 & 0.608 & 0.805 & 0.620 \\
\hline $\mathrm{BP}$ & 8 & 0.308 & 0.390 & 0.284 & 0.276 & 0.512 & 0.478 & 0.907 & 0.454 \\
\hline $\mathrm{VT}$ & $9 a$ & 0.373 & 0.146 & 0.192 & 0.325 & 0.481 & 0.575 & 0.431 & 0.745 \\
\hline $\mathrm{VT}$ & $9 e$ & 0.511 & 0.306 & 0.351 & 0.360 & 0.522 & 0.615 & 0.469 & 0.621 \\
\hline $\mathrm{VT}$ & $9 \mathrm{~g}$ & 0.403 & 0.419 & 0.373 & 0.447 & 0.500 & 0.681 & 0.542 & 0.731 \\
\hline $\mathrm{VT}$ & $9 i$ & 0.391 & 0.421 & 0.304 & 0.361 & 0.542 & 0.697 & 0.493 & 0.776 \\
\hline
\end{tabular}

The correlation between domains and scales of the Yoruba version of SF-36 (internal consistency of the scales and domains) are presented in Table 7. The result shows that correlations between scales and hypothesized domains (PC and $\mathrm{MC}$ ) were above 0.50 (except the correlations between $\mathrm{GH}$ and each of $\mathrm{PC}(r=0.477)$ and MC (0.28). The highest scale-domain correlation was between RE and MC $(r=0.826)$ and RP and MC (0.826).
PC was strongly correlated $(\geq 0.70)$ with each of PF $(r=0.711), \mathrm{RP}(0.823)$ and BP $(0.700)$ while MC was strongly correlated with each of RE (0.826), SF (0.811), $\mathrm{MH}$ (0.789) and VT (0.793). Intra-Class Correlation (ICC) of scores on the Yoruba SF-36 on two occasions (test-retest reliability) $(n=249)$ is presented in Table 8 . The ICC ranges between 0.636 and 0.843 for scales, and between 0.783 and 0.851 for domains. 
Table 5 Independent $t$-test comparison of scales and domains score of the Yoruba version of the SF-36 by gender

\begin{tabular}{|c|c|c|c|c|}
\hline & \multicolumn{2}{|l|}{ Gender } & \multirow[b]{3}{*}{ t-cal } & \multirow[b]{3}{*}{ p-value } \\
\hline & Men & Women & & \\
\hline & $\bar{x} \pm \operatorname{SD}(n=657)$ & $\bar{x} \pm \operatorname{SD}(n=430)$ & & \\
\hline \multicolumn{5}{|l|}{ Scale } \\
\hline $\mathrm{GH}$ & $87.2 \pm 14.7$ & $86.4 \pm 20.6$ & 0.355 & $0.022^{*}$ \\
\hline PF & $87.0 \pm 17.8$ & $84.7 \pm 18.7$ & 1.686 & 0.083 \\
\hline $\mathrm{RP}$ & $86.1 \pm 23.7$ & $83.6 \pm 25.0$ & 1.659 & $0.054^{*}$ \\
\hline RE & $85.0 \pm 28.2$ & $80.6 \pm 30.0$ & 2.454 & $0.013^{*}$ \\
\hline SF & $85.7 \pm 17.7$ & $82.8 \pm 18.7$ & 2.597 & $0.005^{*}$ \\
\hline $\mathrm{MH}$ & $88.7 \pm 13.3$ & $89.0 \pm 13.4$ & -0.385 & 0.465 \\
\hline $\mathrm{BP}$ & $86.4 \pm 17.2$ & $82.4 \pm 18.4$ & 3.626 & $0.008^{*}$ \\
\hline VT & $87.3 \pm 15.1$ & $85.9 \pm 15.9$ & 1.490 & 0.288 \\
\hline \multicolumn{5}{|c|}{ Domain } \\
\hline$P C$ & $85.8 \pm 14.0$ & $85.4 \pm 13.2$ & 0.215 & 0.554 \\
\hline$M C$ & $86.7 \pm 15.4$ & $84.7 \pm 15.2$ & 1.475 & 0.487 \\
\hline
\end{tabular}

* indicate significance at $p<0.05$

Key: Scales; physical functioning (PF), role limitations due to physical problems $(R P)$, bodily pain $(B P)$, general health $(G H)$, vitality $(V T)$, social functioning $(S F)$, role limitations due to emotional problems $(R E)$, and mental health $(M H)$. Domains: physical health component $(P C)$ and mental health components $(M C)$

\section{Discussion}

Translation and cross-cultural adaptation of HRQoL tools to languages other than the original population from which the tool was developed enhances understanding and facilitate acceptance of the tool by the
Table 7 Correlation of physical health components and mental health domains (in horizontal axis) with the 8 scales (vertical axis) in Yoruba version of SF-36 $(n=1087)$

\begin{tabular}{lllllc}
\hline & \multicolumn{2}{l}{ Level of association } & & \multicolumn{2}{l}{ Value of correlation } \\
\cline { 2 - 3 } Scales & $\begin{array}{l}\text { Physical health } \\
\text { component }\end{array}$ & $\begin{array}{l}\text { Mental health } \\
\text { component }\end{array}$ & & $\begin{array}{l}\text { Physical health } \\
\text { component }\end{array}$ & $\begin{array}{l}\text { Mental health } \\
\text { component }\end{array}$ \\
\hline GH & $*$ & - & 0.477 & 0.280 \\
$\mathrm{PF}$ & + & $*$ & 0.711 & 0.516 \\
$\mathrm{RP}$ & + & $*$ & 0.823 & 0.545 \\
$\mathrm{RE}$ & $*$ & + & 0.549 & 0.826 \\
$\mathrm{SF}$ & $*$ & + & 0.660 & 0.811 \\
$\mathrm{MH}$ & $*$ & + & 0.520 & 0.789 \\
$\mathrm{BP}$ & + & $*$ & 0.700 & 0.612 \\
$\mathrm{VT}$ & $*$ & + & 0.562 & 0.793 \\
\hline
\end{tabular}

+: strong association $(r>0.70)$; *: moderate association $(0.30<r<0.70)$; - :weak association $(r<0.30)$. Key: Scales: physical functioning $(P F)$, role limitations due to physical problems $(R P)$, bodily pain $(B P)$, general health $(G H)$, vitality $(V T)$, social functioning $(S F)$, role limitations due to emotional problems $(R E)$, and mental health $(M H)$. Domains: physical health component $(P C)$ and mental health components $(M C)$

accessible population [31-33]. This study was conducted to cross-culturally adapt the SF-36 into Yoruba language and determine its reliability and validity. A response rate of $98.8 \%$ was achieved in this study, therefore, suggesting that the Yoruba SF-36 was an acceptable tool for measuring HRQoL in the Yoruba population. Based on difficulty and quality rating, the Yoruba SF-36 had a high rate of data completion with good quality data in the study population.

Table 6 One way ANOVA comparison of the Yoruba version of the SF-36 scales and domains by age group

\begin{tabular}{|c|c|c|c|c|c|c|c|}
\hline & \multicolumn{5}{|l|}{ Age group } & \multirow[b]{3}{*}{ F-ratio } & \multirow[b]{3}{*}{$p$-value } \\
\hline & $18-24$ & $25-34$ & $35-44$ & $45-54$ & $\geq 55$ & & \\
\hline & $(\bar{x} \pm S D)(n=475)$ & $(\bar{x} \pm S D)(n=447)$ & $(\bar{x} \pm S D)(n=79)$ & $(\bar{x} \pm \operatorname{SD})(n=51)$ & $(\bar{x} \pm S D)(n=35)$ & & \\
\hline \multicolumn{8}{|l|}{ Scale } \\
\hline $\mathrm{GH}$ & $89.5 \pm 12.3$ & $90.7 \pm 10.7$ & $78.1 \pm 27.5$ & $62.3 \pm 23.9$ & $64.8 \pm 33.6$ & 15.795 & $0.001^{*}$ \\
\hline PF & $86.9 \pm 19.7$ & $85.3 \pm 16.9$ & $90.2 \pm 13.8$ & $84.2 \pm 16.7$ & $74.8 \pm 20.1$ & 3.418 & $0.009^{*}$ \\
\hline $\mathrm{RP}$ & $86.1 \pm 23.4$ & $85.8 \pm 23.6$ & $88.61 \pm 20.33$ & $72.1 \pm 33.8$ & $74.3 \pm 27.4$ & 6.242 & $0.001^{*}$ \\
\hline RE & $82.5 \pm 29.6$ & $84.9 \pm 27.9$ & $92.4 \pm 18.5$ & $68.0 \pm 38.3$ & $74.3 \pm 28.1$ & 6.926 & $0.001^{*}$ \\
\hline SF & $84.5 \pm 17.4$ & $85.8 \pm 17.8$ & $88.3 \pm 16.0$ & $77.7 \pm 22.5$ & $73.2 \pm 23.5$ & 6.706 & $0.001^{*}$ \\
\hline $\mathrm{MH}$ & $86.7 \pm 14.4$ & $90.5 \pm 12.5$ & $92.4 \pm 11.1$ & $88.1 \pm 11.4$ & $89.3 \pm 11.8$ & 6.341 & $0.001^{*}$ \\
\hline $\mathrm{BP}$ & $83.8 \pm 18.5$ & $85.4 \pm 17.2$ & $88.0 \pm 15.7$ & $87.2 \pm 15.6$ & $79.6 \pm 19.3$ & 2.115 & 0.077 \\
\hline VT & $83.0 \pm 17.4$ & $90.1 \pm 12.5$ & $91.8 \pm 13.0$ & $85.6 \pm 14.9$ & $85.1 \pm 15.6$ & 15.489 & $0.001^{*}$ \\
\hline \multicolumn{8}{|c|}{ Domain } \\
\hline$P C$ & $86.9 \pm 12.6$ & $86.1 \pm 14.7$ & $85.0 \pm 12.7$ & $72.5 \pm 14.7$ & $85.6 \pm 9.6$ & 3.121 & $0.016^{*}$ \\
\hline$M C$ & $84.2 \pm 15.3$ & $87.8 \pm 14.4$ & $91.1 \pm 12.2$ & $79.8 \pm 20.8$ & $80.5 \pm 17.7$ & 8.741 & $0.001^{*}$ \\
\hline
\end{tabular}

Level of significance was set at $p<0.05$

Key: Scales: physical functioning $(P F)$, role limitations due to physical problems $(R P)$, bodily pain $(B P)$, general health $(G H)$, vitality $(V T)$, social functioning $(S F)$, role limitations due to emotional problems $(R E)$, and mental health $(M H)$. Domains; physical health component $(P C)$ and mental health components $(M C)$ 
Table 8 Intra-Class Correlation of scores on the Yoruba SF-36 on two occasions (test-retest reliability) $(n=249)$

\begin{tabular}{ccccc}
\hline & ICC & \multicolumn{2}{c}{$95 \%$ confidence interval } & $p$-value \\
\cline { 3 - 4 } & & Lower bound & Upper bound & \\
\hline Scale & & & & \\
GH & 0.636 & 0.451 & 0.768 & $0.001^{*}$ \\
PF & 0.802 & 0.747 & 0.846 & $0.001^{*}$ \\
RP & 0.785 & 0.732 & 0.829 & $0.001^{*}$ \\
RE & 0.715 & 0.647 & 0.771 & $0.001^{*}$ \\
SF & 0.777 & 0.722 & 0.823 & $0.001^{*}$ \\
MH & 0.843 & 0.802 & 0.876 & $0.001^{*}$ \\
BP & 0.768 & 0.710 & 0.815 & $0.001^{*}$ \\
VT & 0.796 & 0.745 & 0.838 & $0.001^{*}$ \\
Domain & & & & \\
PC & 0.783 & 0.657 & 0.866 & $0.001^{*}$ \\
MC & 0.851 & 0.813 & 0.883 & $0.001^{*}$ \\
\hline
\end{tabular}

Key: Scales; physical functioning (PF), role limitations due to physical problems $(R P)$, bodily pain $(B P)$, general health $(G H)$, vitality $(V T)$, social functioning $(S F)$, role limitations due to emotional problems $(R E)$, and mental health $(M H)$. Domains; physical health component $(P C)$ and mental health components $(M C)$

The concurrent validity of the Yoruba SF-36 was high, with scales and domains having co-efficient ranges greater than 0.70 that was considered desirable for good validity of a new tool. The correlation coefficient ranges for concurrent validity obtained in this study, is consistent with scales and domains ranges of 83.2 to 88.8 ; and 85.6 and 85.9 respectively reported in previous studies [34-41]. From this study, all scale scores showed negative skewness among the sample population, implying that respondents gave answers that tilt towards the positive end of the health spectrum. Skewness distribution of the Yoruba SF-36 scales follows a similar pattern to previous findings on SF-36 in Hong Kong [36], Australia [37], Netherland [30], New Zealand [41], Brazil [42], Malaysia [20] and Turkey [16] among others.

The result of test of the known-group validity of the Yoruba SF-36 indicated that many dimensions of the SF36 are influenced by socio-demographic variables such as age and gender. Men had higher mean scores in all scales (except $\mathrm{MH}$ ) and domains. This finding is consistent with previous reports $[11,14,39,42]$. However, the reason for higher HRQoL scores in men is still a subject of debate. Hopman et al. [39] implicated poorer HRQoL scores among women on higher incidences of psychological symptoms and greater psychological distress compared with men; in addition, women are more expressive of their symptoms and wellbeing. The finding of this study also showed that all the scales (except BP) and domains were associated with age. There was an obvious decline in mean score with older age across different scales and domains except within the 35-44 years age bracket. The result also revealed that that subscales of $\mathrm{PC}$ (i.e. PF, GH, BP and RP) decreased with older age, while age seem to have less influence on subscales of $\mathrm{MC}$ (MH, RE, SF and VT). This finding is also consistent with earlier reports [35, 37, 39, 41, 42].

The finding of this study showed a high level of itemscale correlations (i.e., correlations of an item with its own scale) greater than minimum value of 0.4 recommended by Ware et al. [10]. The finding showed that definite scaling success was met because the difference between the item-hypothesized scale and item-other scale correlation were $>2$ S.D. (i.e. $>0.15$ ) as recommended [10]. All items in the Yoruba SF-36 correlated strongly with its hypothesized scale than with scales measuring other concepts except the correlation of item 1 (i.e." in general would you say your health is?") of GH with RE, SF, BP and VT scales. Also, item-scale correlations were comparable within each scale, except item 1 which is similar to the findings of a previous study by Sararaks et al. [20]. Therefore, the pattern of item-scales correlation in this study was consistent with the recommendations for good psychometric criteria for SF-36 translations and cultural adaptions [31, 32, 34-41]. In addition, the test-retest results of the Cronbach's $\alpha$ and ICC confirm high reliability of the Yoruba SF-36 at the level of scales and domains, greater than 0.7 coefficient level for good reliability for group-level analyses [8, 42-44].

This study's findings on concurrent and discriminant validity, reliability and internal consistency indicates that the Yoruba SF-36 is a valid tool to assess HRQoL among Yoruba populace. The Yoruba SF-36 showed excellent psychometric properties comparable to the original American and other versions. However, item 1 ("In general would you say your health is?") was poor on discriminant validity scores. Caution is recommended in the interpretation of the finding on item ' 1 ' pending further studies. To validate the findings on the Yoruba SF36 obtained in this study, further studies among various in health and disease populations are needed. The heterogeneity of sample population, mixed methods of sampling and using distance between two adjacent electric poles as equivalence of one block are potential limitations of this study.

\section{Conclusion}

The data quality, concurrent and discriminant validity, reliability and internal consistency of the Yoruba version of the SF-36 are adequate and it is recommended for measuring health-related quality of life among Yoruba population. 


\section{Appendix}

\section{Yoruba Version of the SF-36 (İWÉ ASE İWÁDî́ İLERA - SF-36)}

İLÀNÀ: Àtòjọ ìbéèrè wọ̀nyí fẹ́ mọ̀ nípa ìhà tí o kọ sí ìlera rẹ. İlànà ìbeèrè wọ̀nyí yóò fi bí ìlera rẹ e rí hàn àti bí o șe ní ilera láti máa șe àwọn ohun àmúșe rẹ gbogbo. Dáhùn gbogbo ìbéèrè nípa títọoḳa sí ìdáhùn gẹ́gẹ bó șe yẹ. Bí àtidáhùn ìbéèrè kan bá rú ọ lójú, pèsè ìdáhùn tó yẹ jù lọ bí o șe yé ọ sí.

1. (Jọ̀wọ́ șàmì sí àkámọ́ ìdáhùn kan) Lákòótán, ǹjẹ́ o lè sọ pé ìlera rẹ
Dára jù lọ
Dára púpọ
Dára
Dára díẹ̀
Kò dára
[ ]
[ ]
[ ]
[ ]

2. Ní àfiwé pèlú ọdún kan séyìn, báwo ni o e lè gbé ìlera rẹ lé orí òșùwọ̀n lápapọ̀ báyìn? (Jọ̀wọ́ sàmì sí àkámộ ìdáhùn kan)

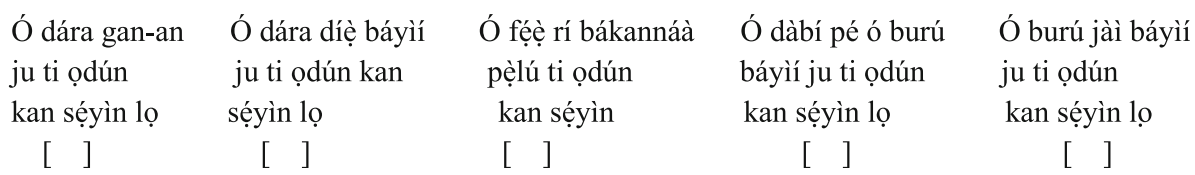

3. Àwọn ìbéèrè wọ̀nyí dá lórí ohun àmúṣe tí ó lè șe ní ọjọ́ kọọ̣kan. Ǹjẹ ìlera rẹ báyií ń se ìdíwọ́ fún o láti se àwọn ohun àmúșe wọ̀nyí? Bó bá rí bẹeẹ̀, báwo ló șe díwọ̀n tó? (Jộwọ́ yí òdo sí nọ́ bà kan lórí ìlà kọ̀ọ̀kan)

\begin{tabular}{|c|c|c|c|}
\hline Oun àmúșe & Bẹeẹ ni, ó șe idíwọ́ púpọ̀ & Bẹeẹ ni, ó șe ìdíwọ́ diệ & Kò sí ìdíwọ́ rárá \\
\hline $\begin{array}{l}\text { 3(a) Àwọn oun àmúșe tó nira bíi eré-sísá, gbígbé ohun tó wúwo, } \\
\text { kíkópa nínú àwọn eré-idárayá tó gba agbára. }\end{array}$ & 1 & 2 & 3 \\
\hline $\begin{array}{l}\text { 3(b) Àwọn ohun àmúșe tí kò ju arà lọ bíi sísún tábilì, fífọ ilẹ pẹ̀lú } \\
\text { mọộu, ọà títa, tàbí gọ́fù gbígbá. }\end{array}$ & 1 & 2 & 3 \\
\hline 3(d) Títarù tàbí gbígbé àwọn ohun èlò tí ara lọjà. & 1 & 2 & 3 \\
\hline 3(e) Gígun àtẹgùn ọlọ́pọ̀ ìpele & 1 & 2 & 3 \\
\hline 3(ẹ) Gígun àtègùn onípele kan. & 1 & 2 & 3 \\
\hline 3(f) Títẹ̀ba, kíkúnlẹ tàbí lílóșòó & 1 & 2 & 3 \\
\hline 3(g) Rírìn ju ibùșọ̀ kan lọ & 1 & 2 & 3 \\
\hline 3(gb) Rírin ọ̀pọ̀lopọ̀ òpó iná & 1 & 2 & 3 \\
\hline 3(i) Rírin òpó iná ẹộà̀n si òmíràn & 1 & 2 & 3 \\
\hline 3(h) Wíwè̀ tàbí mímúra fún'raà rẹ & 1 & 2 & 3 \\
\hline
\end{tabular}

4. Lááárín ò̀sè mẹ́rin sẹ́yìn, ǹjẹ́ o ní àwọn ìsòoro wọ̀nyí pẹ̀lú iṣẹ́ rẹ tàbí àwọn ohun àmúṣe ojoojúmọ́ mìrràn látàrí ìlera afojúrí rẹ? (Jọ̀wọ́ yí òdo sí nọ́ bà kan lórí ilà kọọ̣kan)

\begin{tabular}{|c|c|c|}
\hline & Bẹeẹ̀ ni & Bẹẹ̀ kọ́ \\
\hline 4(a) Ó dínye àkókò tí ò ń lò lẹ́nu ișẹ́ tàbí ohun àmúșe miíràn kù. & 1 & 2 \\
\hline 4(b) Șe kéré ju bí oti fẹ́ & 1 & 2 \\
\hline 4(d) Șe ìdíwọ́ fún ișẹ́ tàbí àwọn ohun àmúșe mìiràn & 1 & 2 \\
\hline 4(e) O ní ìnira láti șe ișẹ́ tàbí àwọn ohun àmúșe miíràn (fún àpẹerẹ, ó gba okun tó ta yọ) & 1 & 2 \\
\hline
\end{tabular}


5. Láàárín òsè mérin séyìn, ǹjẹ́ o ní èyíkéyìi nínú ọgoọoọ̀ọ̀ ìṣòro wọ̀nyí pẹ̀lú ișé rẹ tàbí àwọn ohun àmúṣe ojoojúmọ́ mìrràn látàrí àwọn ìsòro tó jẹ mộrònú (bi àpẹerẹe: nî̀rẹ̀wẹ̀sì tàbí hílàhílo)? (Jọ̀wọ́ yí òdo sí nọ́ bà kan lórí ìlà kọ̣ộkan)

\begin{tabular}{lll}
\hline & Bẹ́ẹ̀ ni & Bẹeẹ̀ kọ́ \\
5(a) Ó dínye àkókò tí ò ń lò lẹ́nu ișé tàbí ohun àmúșe miirràn kù. & 1 & 2 \\
5(b) Șe kéré ju bí oti fẹ́. & 1 & 2 \\
5(d) O ò șișẹ́ tàbí àwọn ohun àmúș̣e miíràn pẹ̀lú îfarabalẹ gẹ́gẹe bí ó șe ń șe é tẹelẹ.. & 1 & 2 \\
\hline
\end{tabular}

6. Lááárín ọ̀sè mệrin séyìn, báwo ni ìlera afojúrí rẹ tàbí àwọn ìșòro tó jẹ mọ́rònú șe nípa tó lórí ìbásepọ rẹ pẹ̀lú ẹbí, ọ̀rẹ́, alábàágbépọ̀ tàbí àwọn ẹgbẹ́ mìrràn? (Jọ̀wọ́ sàmì sí àkámọ́ ajẹmọ́dàáhùn kan)

$\begin{array}{ccccc}\text { Kò ní rárá } & \text { Ó wà ránpẹ́ } & \text { Ó mọ níwọ̀nba } & \text { Ó wà lọ́pọ̣ } & \text { Ó kọjá àfaradà } \\ \text { [ ] } & {[\text { ] ] }} & {[\text { ] }} & \text { [ ] } & \text { [ ] }\end{array}$

7. Láàárín ọ̀sè mẹ́rin sẹ́ỳn, báwo ni ìrora ara tí o ní șe pọ̀ tó? (Jọ̀wọ́ àmì sí àkámọ́ ajẹmọ́dààhùn kan)

$\begin{array}{cccccc}\text { Kò sí } & \text { Kò pọ rárá } & \text { Kò pọ̀ } & \text { ìwònba } & \text { Ó burú } & \text { Ó burú púpọ̀ } \\ \text { [ ] } & {[\text { [ ] }} & {[\text { ] }} & {[\text { ] }} & \text { [ ] } & \text { [ ] }\end{array}$

8. Láàárín òsè mérin séyìn, báwo ni ìrora șe nípa lórí ișẹ òòjộ rẹ sí (Tó fi mọ́ iṣẹ tòde àti ilé)? (Jọ̀wọ́ àmì sí àkámọ́ ajẹmọ́dàáhùn kan)

$\begin{array}{ccccc}\text { Kò nípa rárá } & \text { Ó nípa fẹeẹerẹefẹ́ } & \text { Ó mọ níwọ̀n ba } & \text { Ó nípa lọ̣pọ̀ } & \text { Ó kọjá àfaradà } \\ {[\text { [ ] }} & {[\text { [ ] }} & {[\text { [ ] }} & {[\text { [ ] }} & \text { [ ] }\end{array}$

9. Àwọn ìbéèrè wọ̀nyí dá lórí ìmọ̀lára rẹ àti bí àwọn nǹkan șe rí fún ọ láàrin ọ̀sè̀ mẹ́rin sẹ́yìn. (Jòwọ́ fún wa ní ìdáhùn tó șúnmọ́ bí ìmọ̆lára rẹ șe rí jù lọ sí ìbéèrè kọoọ̀kan)

\begin{tabular}{|c|c|c|c|c|c|c|}
\hline & İgbà Gbogbo & Lọ́pọ̀ l̀bà & Níwọ̀n İgbà Díẹ & Ní àwon igbà kan & Lẹẹẹoọộkan & Kò sígbà kankan \\
\hline 9(a) Ńjẹ́ o mọ̀ ọ́ lára pé ara rẹ gbá yágí tẹ́lẹ rí? & 1 & 2 & 3 & 4 & 5 & 6 \\
\hline 9(b) Ńjẹ́ aláiníbàlè ara ni ộ? & 1 & 2 & 3 & 4 & 5 & 6 \\
\hline $\begin{array}{l}\text { 9(d) Nieé o ti ní îpòrúru ọkàn débi pé kò sí ohun } \\
\text { tó lè tú ọ lára ká? }\end{array}$ & 1 & 2 & 3 & 4 & 5 & 6 \\
\hline 9(e) Ńjẹ oní ỉbàlẹ ọkàn àti àlàáfià? & 1 & 2 & 3 & 4 & 5 & 6 \\
\hline 9(ẹ) Njeẹ o ní okun púpọ̀ tẹ́lẹ rí? & 1 & 2 & 3 & 4 & 5 & 6 \\
\hline 9(f) Njjẹe oti ní ibànújẹ́ àti ọbẹe-ọkàn? & 1 & 2 & 3 & 4 & 5 & 6 \\
\hline 9(g) Njjẹ o mọ̀ ọ́ lára pé o rẹ ọ́ dénú tẹelè rí? & 1 & 2 & 3 & 4 & 5 & 6 \\
\hline 9(gb) Njeẹ o mọ̀ ọ́ lára pé inú rẹ máa ń dùn? & 1 & 2 & 3 & 4 & 5 & 6 \\
\hline 9(i) Njẹe o mọ̀ ọ́ lára pé ó rẹ̀ ọ tẹ́lè rí? & 1 & 2 & 3 & 4 & 5 & 6 \\
\hline
\end{tabular}

10. Láàárín ò̀sè mẹ́rin sẹ́yìn, báwo ni àwọn ìșòro afojúrí tàbí àwọn ìsòro tó jẹ mọ́rònú rẹ șe nípa tó lórí ohun àmúșe àwùjọ rẹ (gẹ́gẹ bí i bíbẹ àwọn ọ̀rẹ́ àti mọ̣lẹ́bí wò, àti bẹẹ̣ bẹẹ̣ lọ.) (Jộoọ șàmì sí àkámọ́ ajẹmọ́dàáhùn kan)

$\begin{array}{ccccc}\text { İgbà gbogbo } & \text { Lọ́pọ̀lọpọ̀ ìgbà } & \text { Ní àwon ìgbà kan } & \text { Lẹẹ̣kọ̣ộkan } & \text { Kò sí ìgbà kankan } \\ \text { [ ] } & {[\text { ] }} & {[\text { [ ] }} & {[\text { ] }} & {[\text { ] }}\end{array}$




\section{Báwo ni ọ̀kọọ̀kan àwọn ìpèdè wọ̀nyí șe jẹ IRỌ́ tàbí ÒTÍTọ́ fún ọ sí? (Jọ̀wọ́ yí òdo sí nọ́ḿbà kan lórí ìlà kọoộkan)}

\begin{tabular}{|c|c|c|c|c|c|}
\hline & Dájúdájú òtítọ́ ni & Òtítọ́ ni ní ọ̀pọ̀ ìgbà & N kò mọ̀ & Irọ́ ni ní ọ̀pọ̀ ìgbà & Dájúdájú Irọ́ ni \\
\hline $\begin{array}{l}11 \text { (a) Ó dàbí pé mo máa ń tètè șàișàn ju àwọn ènìyàn } \\
\text { miiràn lọ }\end{array}$ & 1 & 2 & 3 & 4 & 5 \\
\hline 11 (b) ìlera mi dára gẹgẹ́ bíi àwọn ènìyàn tí mo mọ̀ & 1 & 2 & 3 & 4 & 5 \\
\hline 11(d) Mo ní ìrètí pé ilera mi yóò burú sí i. & 1 & 2 & 3 & 4 & 5 \\
\hline 11(e) Ìlera mi dára jù lọ. & 1 & 2 & 3 & 4 & 5 \\
\hline
\end{tabular}

E șé!

\section{Competing interests}

The authors declare that they have no competing interests.

\section{Authors' contributions}

CEM conceived the idea for this study, participated in data collection, conducted analysis and interpretation of data and prepared the final manuscript for publication. GAA participated in the design of methodology and data collection and drafted the manuscript. MOO, RAA, AA, TOA, OAI and OAO developed the study's methodology and drafted the manuscript. All authors read and approved the final manuscript.

\section{Acknowledgement}

The authors wish to thank the African Population and Health Research Centre (APHRC), Nairobi, Kenya for providing technical support through the African Doctoral Dissertation Research Fellowship (ADDRF) Post-Doctoral Fellowship. We will also like to thank all the respondents for this study.

\section{Author details}

${ }^{1}$ Department of Medical Rehabilitation, College of Health Sciences, Obafemi Awolowo University, Ile - Ife, Nigeria. ${ }^{2}$ African Population and Health Research Center, Nairobi, Kenya. ${ }^{3}$ Department of Physiotherapy, College of Medicine, University of Ibadan, Nigeria, Nigeria. ${ }^{4}$ Department of Mental Health, College of Health Sciences, Obafemi Awolowo University, Ile - Ife, Nigeria. 5 Department of Physiotherapy, School of Basic Medical Sciences, College of Medical Sciences, University of Benin, Benin City, Nigeria.

Received: 11 December 2014 Accepted: 2 September 2015 Published online: 14 September 2015

\section{References}

1. Schölzel-Dorenbos CJM, Krabbe PFM, Olde Rikkert MGM. Quality of Life in Dementia Patients and Their Proxies: A Narrative Review of the Concept and Measurement Scales. Handbook of Disease Burdens and Quality of Life Measures. 2010; p. 3671-3689.

2. Maciejewski M. Generic Measures. In: Kane LR, editor. Understanding Health Care Outcomes Research. Maryland: Aspen: Gaithersburg; 1993.

3. Patrick DL, Erickson P: Health Status and Health Policy. Quality of Life in Health Care Evaluation and Resources Allocation. New York: Oxford University Press; 1993. p. 414-428.

4. Lohr KN. Applications of health status assessment measures in clinical practice. Overview of the third conference on advances in health status assessment. Med Care. 1992;30(5 Suppl):MS1-14.

5. Sanjuas Benito C. Measuring quality of life: generic or specific questionnaires? Arch Bronconeumol. 2005;41:107-9.

6. Klooster PM, Vonkemen HE, Taal E, Siemons L, Hendriks L, De Jong AJL, et al. Performance of the Dutch SF-36 version 2 as a measure of Health-related quality of life in patients with rheumatoid arthritis. Health and Quality of life outcome. 2013;11:77

7. Mcsweeny AJ, Creer TL. Health-related quality of life assessment in medical care. Dis Mon. 1995;41(1):6-71.

8. Streiner D, Norman G. Health measurement scales: a practical guide to their development and use. New York: Oxford University Press; 2008.

9. Ware Jr JE. SF-36 Health Survey Update. In: Maruish M, editor. The Use of Psychological Testing for Treatment Planning and Outcome Assessment, vol. 3. Mahwah, New Jersey: Lawrence Erlbaum Associates; 2004. p. 693-718.
10. Ware JE, Gandek B. Overview of the SF-36 Health Survey and the International Quality of Life Assessment Project. J Clin Epidemiol. 1998;51(11):903-12.

11. Ware JE, Kosinski M, Dewey JE: How to score version 2 of the SF-36 health survey. Lincoln, Rl: QualityMetric Incorporated; 2000.

12. Fukuhara S, Bito S, Green J, Hsiao A, Kurokawa A. Translation, Adaptation and validation of the SF-36 health survey for use in Japan. J Clin Epidemiol. 1998;51(11):1037-44.

13. Asnani M, Lipps G, Reid M. Component structure of the SF-36 in Jamaicans with Sickle cell disease. West Indian Med J. 2007;56(5):491-7.

14. Khader S, Mourani MM, Al-Akour N. Normative data and psychometric properties of short form 36 health survey (SF-36, Version 1.0) in the population of North Jordan. East Mediterr Health J. 2011;17(5):368-74.

15. Ware Jr JE, Sherbourne CD. The MOS 36-Item Short-Form Health Survey (SF-36): I. Conceptual Framework and Item Selection. Med Care. 1992;30:473-83.

16. Demiral Y, Ergor G, Unal B, Semin S, Akvardar Y, Kivircik B, et al. Normative data and discriminative properties of short form 36 SF-36 in Turkish urban population. BMC Public Health. 2006;6:247.

17. Cheung GW, Rensvold RB. Evaluating goodness-of-fit indexes for testing measurement invariance. Struct Equ Model. 2002;9:233-55.

18. Sudano JJ, Perzynski A, Love TE, Lewis SA, Murray PM, Huber G, et al. Measuring Disparities: Bias in the SF-36V2 among Spanish-speaking Medical Patients. Med Care. 2011;49(5):480-8.

19. Li L, Wang HM, Shen Y. Chinese SF-36 Health Survey: translation, cultural adaptation, validation, and normalisation. J Epidemiol Community Health. 2003;57:259-63

20. Sararaks S, Azman AB, Low LL, Ugayah BR, Azlah AM, Hooi LN, et al. Validity and Reliability of the SF-36": The Malaysian context. Med J Malaysia. 2005;60:2.

21. Motamed N, Ayatollahi AR, Zare N, Sadeghi-Hassanabadi A. Validity and reliability of the Persian translated of the SF-36 version 2 questionnaire. East Mediterr Health J. 2005;11(3):349-57.

22. Agu KA, Okojie O, Oqua D, King R, Isah M, lyaji PG, et al. Health-Related quality of life and CD4 cells status of patients receiving antiretroviral therapy in Nigeria. West African Journal of Pharmacy. 2012;23(2):87-97.

23. Ewunife OI, Aguwa CN, Adibe MO, Barikpaoar E, Onwuka CJ. Health state utility of a population of Nigerian hypertensive patients. BMC Research Notes. 2011;4:528.

24. Jaiyesimi AO, Sofela EA, Rufai AA. Health related quality of life and its determinants in Nigerian breast cancer patients. Afr J Med Med Sci. 2007;36(3):259-65.

25. Ogunlana MO, Adedokun B, Dairo MD, Odunaya NA. Profile and predictor of health-related quality of life among hypertensive patient in South-western Nigeria. BMC Cardiovascular Disorder. 2009:9:25.

26. Mbada CE, Ayanniyi O, Ogunlade SO, Orimolade EA, Oladiran AB, Ogundele AO. Influence of McKenzie protocol and 2 modes of endurance exercises on Health-Related Quality of Life of patients with Long term mechanical Low-Back Pain. Pan Afr Med J. 2014;18(Suppl 1:5):17.

27. Balogun TA. An Endangered Nigerian Indigenous Language: The Case of Yorùbá Language. African Nebula. 2013;6:70-82.

28. Williamson K, Blench R. Niger-Congo Languages. In: D, Nurse Ed. African Languages: An Introduction. Cambridge: Cambridge University Press; 2000.

29. World Health Organization. Guidelines for conducting community surveys on injuries and violence. Edited by Sethi D, Habibula S, McGee K, Peden M, Bennet S, Hyder AA, Klevens J, Odero W, Suriyawongpaisal P. World Health Organization, Geneva. 2004. http://apps.who.int. Accessed 12 jun 2014. 
30. Aaronson NK, Acquadro C, Alonso J, Apolone G, Bucquet D, Bullinger M, et al. International Quality of Life Assessment Project. Qual Life Res. 1992;1:349-51.

31. Bullinger M, Anderson R, Cella D, Aaronson N. Developing and evaluating cross-cultural instruments from minimum requirements to optimal models. Qual Life Res. 1993;2(6):451-9.

32. Gandek B, Ware J. Methods for validating and norming translations of health status questionnaires: The IQOLA Project approach. J Clin Epidemiol. 1998;51(11):953-9.

33. Acquardo C, Conway K, Hareendran A, Aaronson N. Literature review of methods to translate health-related quality of life questionnaires for use in multinational clinical trials. Value Health. 2008;11(3):509-21.

34. Ware Jr JE, Snow KK, Kosinski M, Gandek B. SF-36 manual and interpretation guide. Boston: The Health Institute, New England Medical Center; 1993.

35. Aaronson NK, Muller M, Cohen PDA, Essink-Bot ML, Fekkes M, Sanderman R. Translation, validation, and norming of the Dutch language version of the SF-36 Health Survey in community and chronic disease populations. J Clin Epidemiol. 1998;51:1055-68.

36. Lam CK, Gandek B, Ren XS, Chan MS. Tests of scaling assumptions and construct validity of the Chinese (HK) version of the SF-36 Health Survey. J Clin Epidemiol. 1998;51(11):1139-47.

37. Butterworth P, Crosier T. The validity of the SF-36 in an Australian National Household Survey: demonstrating the applicability of the Household Income and Labour Dynamics in Australia (HILDA) Survey to examination of health inequalities. BMC Public Health. 2004;4:44.

38. Jenkinson C, Layte R, Lawrence K. Development and testing of the Medical Outcomes Study 36-Item Short Form Health Survey summary scale scores in the United Kingdom. Med Care. 1997;35:410-6.

39. Hopman W, Towheed T, Anastassiades T, Tenenhouse A, Poliquin S, Berger C, et al. Canadian Normative Data for the SF-36 Health Survey. CMAJ. 2000;163(3):265-71.

40. Montazeri A, Goshtasebi A, Vahdaninia M, Gandek B. The Short Form Health Survey (SF-36): translation and validation study of the Iranian version. Qual Life Res. 2005;14(3):875-82.

41. Scott KM, Tobias MI, Sarfati D, Haslett SJ. SF-36 health survey reliability, validity and norms for New Zealand. Aust NZJ Public Health. 1999:23(4):401-6.

42. Cruz LN, Fleck MP, Oliveira MR, Camey SA, Hoffmann JF, Bagattini AM, et al. Health-related quality of life in Brazil: normative data for the SF-36 in a general population sample in the south of the country. Cien Saude Colet. 2013;18(7):1911-21.

43. Nunnally JC, Bernstein IR. Psychometric Theory. 3rd ed. New York: McGraw-Hil; 1994

44. Sheikh KA, Yagoub U, Elsatouhy M, Al Sanosi R, Mohamud SA: Reliability and Validity of the Arabic Version of the SF-36 Health Survey Questionnaire in Population of Khat Chewers - Jazan Region-Kingdom of Saudi Arabia. Applied Research Quality Life. 2013; DOI 10.1007/s11482-013-9291-1

\section{Submit your next manuscript to BioMed Central and take full advantage of:}

- Convenient online submission

- Thorough peer review

- No space constraints or color figure charges

- Immediate publication on acceptance

- Inclusion in PubMed, CAS, Scopus and Google Scholar

- Research which is freely available for redistribution 